\title{
ANTIOXIDANT COMPOUNDS AND TOTAL ANTIOXIDANT ACTIVITY IN FRUITS OF ACEROLA FROM CV. FLOR BRANCA, FLORIDA SWEET AND BRS 366
}

\author{
KELLINA OLIVEIRA DE SOUZA², CARLOS FARLEY HERBSTER MOURA ${ }^{3}$, \\ EDY SOUSA DE BRITO ${ }^{3}$, MARIA RAQUEL ALCÂNTARA DE MIRANDA ${ }^{4}$
}

\begin{abstract}
Information on antioxidant properties at different ontological stages may help producers and food technologists to identify which cultivar and/or maturity stage are most adequate for their need, therefore this work aimed to study the changes in the antioxidant metabolism during acerola development. Fruit from cv. Flor Branca, BRS366 and Florida Sweet were harvested at different stages: immature green colored (I), physiologically mature with green color and maximum size (II), breaker (III) and full red ripe (IV). After harvest, fruits were selected, divided into four replications with $500 \mathrm{~g}$ each and evaluated regarding their titratable acidity, $\mathrm{pH}$, soluble solids, total soluble sugar, vitamin $\mathrm{C}$, polyphenol, anthocyanin, yellow flavonoid, total antioxidant activity and antioxidant enzyme activity. Anthocyanin and flavonoid were determined through LC-DAD-ESI/MS and all analysis followed a completely randomized factorial $3 \times 4$ design. Fruits of 'Florida Sweet' presented significantly higher soluble solids $\left(9.46^{\circ}\right.$ Brix $)$. Vitamin C content decreased during ripening, but ripe 'BRS 366' fruits showed the greatest values (1363 mg.100 g ${ }^{-1}$ ) and highest TAA with $42.36 \mu \mathrm{M}$ TEAC. ${ }^{-1} \mathrm{FW}$. Cyanidin 3-rhamnoside (520.76 mg.100 $\left.\mathrm{g}^{-1} \mathrm{DM}\right)$ and quercetin 3-rhamnoside (33.72 mg.100 g-1 DM) were the most abundant anthocyanin and yellow flavonoids found mainly in 'Flor Branca' fruit of acerola, whose antioxidant enzymes activities were also higher. Ripe 'Florida Sweet' fruit presents a great potential for fresh consumption, meanwhile physiologically mature 'BRS 366' fruit seems the best option for the bioactive compounds processing industry. As 'Flor Branca' fruit of acerola kept the highest activity levels, it could be an indicative of greater potential for postharvest conservation.
\end{abstract}

Index Terms: Malpighia emarginata, development, vitamin C, enzymes, polyphenols.

\section{COMPOSTOS ANTIOXIDANTES E ATIVIDADE ANTIOXIDANTE TOTAL EM FRUTOS DAS VARIEDADES FLOR BRANCA, FLORIDA SWEET E BRS 366 DE ACEROLEIRA}

\begin{abstract}
RESUMO - Informações sobre propriedades antioxidantes em diferentes estádios ontológicos podem ajudar os produtores e tecnólogos de alimentos a identificar quais cultivares e/ou estádio de maturidade são os mais adequados para a sua necessidade; portanto, o objetivo deste trabalho foi estudar as alterações no metabolismo antioxidante durante o desenvolvimento de frutos da aceroleira. Frutos das cv. FlorBranca, BRS 366 e Florida Sweet foram colhidos em diferentes estádios: imaturos com cor verde (I), fisiologicamente maduros com cor verde e tamanho máximo (II), com cor predominantemente vermelha (III) e totalmente vermelha, maduro (IV). Após a colheita, os frutos foram selecionados, divididos em quatro repetições com $500 \mathrm{~g}$ cada e avaliados quanto à acidez titulável, $\mathrm{pH}$, sólidos solúveis, açúcares solúveis totais, vitamina $\mathrm{C}$, polifenóis, antocianinas, flavonoides amarelo, atividade antioxidante total e atividade de enzimas antioxidantes. Antocianina e flavonoides foram determinados por meio LC-DAD-ESI/MS, e todas as análises seguiram um delineamento experimental inteiramente casualizado, em esquema fatorial 3 $\mathrm{x}$ 4. Frutos de aceroleira 'Florida Sweet' apresentaram níveis significativamente mais elevados de sólidos solúveis $\left(9,46^{\circ} \mathrm{Brix}\right)$. $\mathrm{O}$ conteúdo de vitamina $\mathrm{C}$ diminuiu durante o amadurecimento, porém frutos de aceroleira 'BRS 366' maduras apresentaram os maiores valores $\left(1.363 \mathrm{mg} .100 \mathrm{~g}^{-1}\right)$ e maior TAA com 42,36 $\mathrm{mM}$ TEAC. $\mathrm{g}^{-1}$. Cianidina 3-ramnosideo $\left(520,76 \mathrm{mg} .100 \mathrm{~g}^{-1} \mathrm{MS}\right)$ e quercetina 3-ramnosideo (33,72 mg.100 $\mathrm{g}^{-1} \mathrm{MS}$ ) foram as antocianinas e flavonoides amarelos mais abundantes encontrados nos frutosda variedade 'Flor-Branca', cujas atividades das enzimas antioxidantes também foram superiores. Frutos de aceroleira 'Florida Sweet' maduros apresentam grande potencial para o consumo in natura, enquanto frutos da 'BRS 366 ' fisiologicamente maduros parecem ser a melhor opção para a indústria de processamento de compostos bioativos. Como frutos de acerola 'Flor-Branca' mantiveram os mais altos níveis de atividade antioxidante, este pode ser um indicativo de maior potencial para a conservação pós-colheita.
\end{abstract}

Termos de indexação: Malpighia emarginata, desenvolvimento, vitamina C, enzimas, polifenóis.

\footnotetext{
(Trabalho 410-13). Recebido em: 16-10-2013. Aceito para publicação em: 05-02-2014.

${ }^{2}$ Mestre em Fitotecnia, UFC, Av. Mr. Hull 2297, Campus do Pici, Fortaleza-CE, Brasil. E- mail:kellina@gmail.com

${ }^{3}$ Pesquisador,Embrapa Agroindústria Tropical, Fortaleza-CE, Brasil. E-mails: farley.moura@embrapa.br, edy.brito@embrapa.br

${ }^{4}$ Prof. Adjunta, UFC, Av. Mr. Hull 2297, Campus do Pici, Fortaleza-CE, Brasil; E-mail: rmiranda@ufc.br
} 


\section{INTRODUCTION}

Fruit consumption has been extensively associated to decreases in cardiovascular disease and cancer risks supported by substantial epidemiological evidence (SILVA et al., 2004; AGUDO et al., 2007;). This beneficial effect is mainly due to the presence of antioxidants that neutralize or scavenge reactive species or free radicals thereby, reducing oxidative damage to the cell metabolism. The antioxidant cell defense system is constituted of enzymes that act in concert with non-enzymatic compounds through synergistic or antagonistic interactions contributing to the equilibrium between radical production and elimination.

Previous works showed that acerola presented high levels of both enzymes and nonenzymatic compounds with antioxidant activity (OLIVEIRA et al., 2011; OLIVEIRA et al., 2012), implying therefore, a great potential for human health promotion and for extension of postharvest conservation period. As stated by Lacan and Baccou (1998) when studying melon varieties, those fruit with higher antioxidant levels were able to be stored for longer periods, representing an extension in shelflife. However, Menichini et al. (2009) reported that quality and quantity of such bioactive compounds are directly influenced by harvest stage, genotype, climate and cultivation techniques.

In Brazil, growers' interest in acerola increased mainly after 1988 , when consumers worldwide became aware of its awesome vitamin $\mathrm{C}$ levels. Then and initially, the main concern was to establish new varieties which were adapted to the country's northeast region soil and climatic conditions resulting in high yields of quality fruit. Therefore, Embrapa Agroindústria Tropical and others Brazilian research institutions started on breeding programs which resulted in different acerola varieties as Flor Branca and BRS 366, which were launched and recommended for commercial planting by the former institution based on performance of their morphological characteristics, production and fruit quality. Besides those varieties developed in Brazil, others were also imported from abroad as the extraordinarily sweet-flavored 'Florida Sweet' which was established by North-American researchers in Florida and Puerto Rico, EUA.

As other climacteric fruit with a fast ripening metabolism, acerola should be harvested at physiological maturity and may be stored under ambient conditions for only four days or up to 12 days if refrigerated $\left(12^{\circ} \mathrm{C}\right)$ and under PVC film modified storage atmosphere (MOURA et al., 2007). Such short postharvest life, requires that acerola growers have clearly defined which market they will aim at; as for vitamin $\mathrm{C}$ and polyphenol industrial extraction where fruit are processed into powder, capsules or concentrated forms for foodstuff supplementation or as for fresh, frozen fruit or pulp consumers. Based on this data and hoping that information on antioxidant properties at different ontological stages will help producers and food technologists to identify which cultivar and/or maturity stage are most adequate for their need, this work aimed to study the changes in the antioxidant metabolites and in antioxidant capacity during development of acerola fruit from cv. Flor Branca, BRS 366 and Florida Sweet.

\section{MATERIAL AND METHODS}

\section{Fruit material}

Acerola clones: Flor Branca, BRS366 and Florida Sweet were obtained from Embrapa Agroindústria Tropical Experimental Field at Pacajús-CE, Brazil, where they were harvested at different stages according to skin color and size as shown in Figure 1: immature fruits with green color (I), physiologically mature with green color and maximum size (II), breaker - turning red (III) and full red ripe (IV). After harvest, fruits were selected based on homogeneity in color/size and absence of defects, washed in tap water and divided in samples that were evaluated as four replications with $500 \mathrm{~g}$ each. Fruit mass ranged from 3-8 g. Fruit samples were then, processed using a domestic blender Walita, the processed pulp was stored at $-20^{\circ} \mathrm{C}$ and within a 30 day period, was further analyzed as following.

\section{Chemicals}

2,6-Dichloro-indophenol (DFI), FolinCiocalteu Reagent, Formic acid, Acetonitrile, Anthrone, Cyanidin 3-rhamnoside, Quercetin 3-rhamnoside, Pelargonidin 3-rhamnoside, 2,2-Azinobis-3-ethylbenzthiazoline-6-sulphonic acid radical cation $\left(\mathrm{ABTS}^{*+}\right.$ ), 6-Hydroxy-2,5,7,8tetramethylchroman-2-carboxylic acid (Trolox), Ethylenediaminetetracetic acid (EDTA), Nitroblue tetrazolium chloride (NBT) and Hydrogen peroxide $\left(\mathrm{H}_{2} \mathrm{O}_{2}\right)$ were purchased from Sigma Chemical Co. (St. Louis, MO).

\section{antioxidants \\ Quality parameters and non-enzymatic}

Titratable acidity (TA) of acerola pulp was evaluated as determined by AOAC (2005) using an automatic titrator (Mettler-Toledo ${ }^{\circledR}$ DL12, Columbus-USA) and results were expressed as 
$\%$ of malic acid. The $\mathrm{pH}$ was measured using an automatic pHmeter (Labmeter ${ }^{\circledR}$ PHS-3B, São PauloBrazil) as recommended by AOAC (2005). Soluble solids (SS) content was determined by refractometry as described by AOAC (2005) using a digital refractometer $\left(\mathrm{ATAGO}^{\circledR} \mathrm{N} 1\right.$, Kirkland-USA) with automatic temperature compensation. The results were expressed in ${ }^{\circ}$ Brix (concentration of sucrose $\mathrm{w} / \mathrm{w})$. The ratio between soluble solids and titratable acidity (SS/TA) was also calculated. Total soluble sugar content was determined by the Anthone method as described by Yemn and Willis (1954) and results were expressed as percentage, $\%$.

The total vitamin $\mathrm{C}$ was determined by titration with $0.02 \%$ 2,6-dichloro-indophenol (DFI) as method by Strohecker and Henning (1967). One gram of pulp was diluted to $100 \mathrm{~mL}$ of $0.5 \%$ oxalic acid and homogenized. Then, $5 \mathrm{~mL}$ of this solution was diluted to $50 \mathrm{~mL}$ with distilled water and titrated and results were expressed as mg. $100 \mathrm{~g} \mathrm{~g}^{-1} \mathrm{FW}$ (fresh weight). Anthocyanins and yellow flavonoids were extracted and determined as described by Francis (1982). One gram of pulp was extracted with a $95 \%$ ethanol/1.5 N HCl (85:15) solution, vortexed for 2 min and then, brought to $50 \mathrm{~mL}$ with the extracting solution. Protected from the light, the mixture was refrigerated at $4^{\circ} \mathrm{C}$ for 12 hours, then filtered on Whatman N.1 paper and the filtrate was gathered. The absorbance of the filtrate was measured at $535 \mathrm{~nm}$ for the total anthocyanin content using an absorption coefficient of $98.2 \mathrm{~mol} / \mathrm{cm}$ and at 374 $\mathrm{nm}$ for the total yellow flavonoid content using an absorption coefficient of $76.6 \mathrm{~mol} / \mathrm{cm}$. Both results were expressed as mg. $100 \mathrm{~g}^{-1} \mathrm{FW}$.

The total phenol content was measured by a colorimetric assay using Folin-Ciocalteu reagent as described by Ainsworth and Gillespie (2007). Before the colorimetric assay, the samples were subjected to extraction in $50 \%$ methanol and $70 \%$ acetone as described by Larrauri et al. (1997). Extracts were added to $1 \mathrm{~mL}$ Folin Ciocalteau reagent $(1 \mathrm{~N}), 2$ $\mathrm{mL} \mathrm{Na}_{2} \mathrm{CO}_{3}$ at $20 \%$ and $2 \mathrm{~mL}$ of distilled water and absorbance was monitored at $700 \mathrm{~nm}$ and the results were calculated from a standard curve of gallic acid $98 \%(0-50 \mu \mathrm{g})$ and expressed as gallic acid equivalents (GAE) mg. $100 \mathrm{~g}^{-1} \mathrm{FW}$.

Phenols were also determined by liquid chromatography (LC) coupled to mass spectrometer (MS). For extraction, $300 \mathrm{mg}$ of freeze-dried acerola pulp was suspended in $5 \mathrm{~mL}$ of $40 \%$ methanolic solution, vortex-mixed for $1 \mathrm{~min}$ and sonicated for $60 \mathrm{~min}$ prior to centrifugation at $2500 \mathrm{~g}$ for $10 \mathrm{~min}$ at $20^{\circ} \mathrm{C}$. The supernatant was filtered $(0.45 \mu \mathrm{m})$ and then submitted to chromatographic analysis. The LC-
DAD-ESI/MS was a Varian ${ }^{\circledR}$ ProStar system HPLC (Walnut Creek, CA) coupled with a diode array detector (DAD) and a 500-MS IT mass spectrometer (Varian). A Symmetry ${ }^{\circledR}$ C18 column $(5.0 \mu \mathrm{m}, 250$ x $4.6 \mathrm{~mm}$ ) was used at a flow rate of $400 \mu \mathrm{L} . \mathrm{min}^{-1}$. The column oven temperature was set at $30^{\circ} \mathrm{C}$. The mobile phase consisted of a combination of $\mathrm{A}(0.1 \%$ formic acid in milli-Q water $)$ and $B(0.1 \%$ formic acid in acetonitrile). The gradient varied linearly from 10 to $26 \% \mathrm{~B}(\mathrm{v} / \mathrm{v})$ in $40 \mathrm{~min}$, to $65 \% \mathrm{~B}$ at $60 \mathrm{~min}$ and finally, to $100 \%$ B at $70 \mathrm{~min}$ and then, held at $100 \%$ B for $75 \mathrm{~min}$. The DAD was set at 340, 270 and 512 $\mathrm{nm}$ for real-time read-out and UV/VIS spectra from 190 to $650 \mathrm{~nm}$ were continuously collected.

Mass spectra were simultaneously acquired using electrospray ionization in the positive and negative ionization modes (PI and NI) at a fragmentation voltage of $80 \mathrm{~V}$ for the mass range of $200-1000(\mathrm{~m} / \mathrm{z})$. A drying gas pressure of 35 psi, nebulizer gas pressure of $40 \mathrm{psi}$, a drying gas temperature of $370^{\circ} \mathrm{C}$, capillary voltages of $3500 \mathrm{~V}$ for PI and NI, and spray shield voltages of $600 \mathrm{~V}$ were used. The LC system was directly coupled to the MS without stream splitting. Compound identification was primarily based on mass spectrometric data for molecular ions and MS-MS product ions and on published observations for phenolics in fruits and vegetables. Quantification was performed on the basis of UV-Vis data. The UV-visible detector was set to collect the signal at $512 \mathrm{~nm}$ for cyanidin 3-rhamnoside and pelargonidin 3-rhamnoside and $340 \mathrm{~nm}$ for quercetin 3-rhamnoside. External standard curves were used and results were expressed as equivalents (mg). $100 \mathrm{~g}^{-1}$ of dry matter (DM).

\section{Total antioxidant activity}

The total antioxidant activity (TAA) was determined using 2,2-azinobis-3-ethylbenzthiazoline6-sulphonic acid radical cation $\left(\mathrm{ABTS}^{*+}\right.$ ) method as described by Rufino et al. (2006). Before the colorimetric assay, the samples were subjected to a procedure of extraction in 50\% methanol and 70\% acetone (LARRAURI et al., 1997). Once the radical was formed, the reaction was started by adding $30 \mu \mathrm{L}$ of extract in $3 \mathrm{~mL}$ of radical solution, absorbance was measured $(734 \mathrm{~nm})$ after $6 \mathrm{~min}$ and the decrease in absorption was used to calculate the total antioxidant activity (TAA). A calibration curve was prepared and different trolox concentrations (standard trolox solutions ranging from 100 to $2000 \mu \mathrm{M}$ ) were also evaluated against the radical. Antioxidant activity was expressed as trolox equivalent antioxidant capacity (), $\mu$ mol TEAC. $\mathrm{g}^{-1} \mathrm{FW}$. 


\section{Activity of antioxidant enzymes}

Two grams of fruit pulp were homogenized in $10 \mathrm{~mL}$ of $0.1 \mathrm{M}$ potassium phosphate buffer $(\mathrm{pH}$ 7.0) containing $0.1 \mathrm{mM}$ ethylenediaminetetracetic acid (EDTA) for $1 \mathrm{~min}$, followed by centrifugation at $3248 \mathrm{~g}$ for $40 \mathrm{~min}$ at $4^{\circ} \mathrm{C}$ (YANG et al., 2009). The supernatant fraction was used as a crude extract for the enzyme activity assays and all the procedures were performed at $4^{\circ} \mathrm{C}$. The total protein content was determined according to Bradford (1976) using bovine serum albumin (BSA) as a standard.

Superoxide dismutase (SOD, EC 1.15.1.1) activity was determined spectrophotometrically based on inhibition of the photochemical reduction of nitroblue tetrazolium chloride (NBT) (BEAUCHAMP; FRIDOVICH, 1971; GIANNOPOLITIS; RIES, 1977). The reaction mixture absorbance was measured by the Spectrum SP 2000UV Spectrophotometer at $560 \mathrm{~nm}$ and one unit of SOD activity (UA) was defined as the amount of enzyme required to cause a $50 \%$ reduction in the NBT photo-reduction rate. Thus, results were expressed as UA.mg ${ }^{-1} \mathrm{P}$ (protein).

Catalase (CAT, EC 1.11.1.6) activity was measured according to Beers and Sizer (1952). The reaction started by adding the enzyme extract, then, the decrease in hydrogen peroxide $\left(\mathrm{H}_{2} \mathrm{O}_{2}\right)$ was monitored through absorbance at $240 \mathrm{~nm}$ and quantified by its molar extinction coefficient (36 M.cm ${ }^{-1}$ ). One unit of CAT activity (UA) was defined as the amount of enzyme required to decompose $\mathrm{H}_{2} \mathrm{O}_{2}$ and results were expressed as $\mu \mathrm{mol} \mathrm{H}_{2} \mathrm{O}_{2}$. $\mathrm{min}^{-1} \cdot \mathrm{mg}^{-1} \mathrm{P}$.

Ascorbate peroxidase (APX, EC 1.11.1.1) activity was assayed according to Nakano and Asada (1981). Enzyme activity was measured using the molar extinction coefficient for ascorbate (2.8 $\left.\mathrm{mM} . \mathrm{cm}^{-1}\right)$, considering that $1 \mathrm{~mol}$ of ascorbate is required for a reduction of $1 \mathrm{~mol}_{2} \mathrm{O}_{2}$. Results expressed as $\mu \mathrm{mol} \mathrm{H}_{2} \mathrm{O}_{2} \cdot \mathrm{min}^{-1} \cdot \mathrm{mg}^{-1} \mathrm{P}$.

\section{Statistical analysis}

The experimental design was completely randomized in factorial $3 \times 4$ (cultivars $\mathrm{x}$ harvest stage) with four replications with $500 \mathrm{~g}$ each. The data obtained was subjected to analysis of variance (ANOVA) using a computer program (SISVAR 3.01) and the averages were compared by the Tukey test at 5\% probability (GOMES, 1987).

\section{RESULTS AND DISCUSSION}

Quality and non-enzymatic antioxidants

During the ripening (stages III and IV), the soluble solids content was significantly higher and the greatest values were found for 'Florida Sweet' fruit $\left(9.46^{\circ}\right.$ Brix), while the lowest were for 'BRS $366^{\prime}\left(6.33^{\circ}\right.$ Brix) (Table 1). The opposite behavior was observed for titratable acidity which decreased significantly and at stage IV, was lowest in 'Florida Sweet' fruit $(0.61 \%)$ and highest in 'BRS 366' $(1.06 \%)$ although, $\mathrm{pH}$ values only slightly changed (Table 1). These results may be explained as organic acids are converted into sugars by gluconeogenesis, as observed by the increase in sugar content in Table 1, or are consumed as substrates of respiratory process. Corroborating with the above results, stage IV 'Florida Sweet' fruit presented the highest SS/ TA ratio (15.42) (Table 1). It is noteworthy the exceptionally high sugar content found for ripe 'Florida Sweet' acerola fruit, 6.03\%, highlighting its great potential for fresh consumption.

The changes in non-enzymatic antioxidant compounds during acerola development may is shown in Table 2. Vitamin C content decreased more than $40 \%$ during ripening when 'BRS 366' fruit showed the greatest values (1363 mg.100 g-1) and 'Florida Sweet', the lowest (862 mg. $\left.100 \mathrm{~g} \mathrm{~g}^{-1}\right)$. During development, acerola fruit 'BRS 366' presented higher vitamin $\mathrm{C}$ levels, especially at stage I, 2534 mg. $100 \mathrm{~g}^{-1}$. Acerolas fruit cv. BRS 366 and Florida Sweet showed contrasting behavior regarding their sugar (Table 1) and vitamin C contents; as the one with highest vitamin level accumulated less sugar ('BRS 366') and the one with the sweetest fruits had a lower vitamin C concentration ('Florida Sweet'). Despite the observed decline, the evaluated acerola varieties still presented high vitamin $\mathrm{C}$ contents compared to other fruits as orange, guava and cashew apple with $62.50,135.70$ and $279.37 \mathrm{mg} .100 \mathrm{~g} \mathrm{~g}^{-1}$, respectively (COUTO; CANNIATTI-BRAZACA, 2010; SILVA et al., 2010; LOPES et al., 2012).

The polyphenol content of 'Florida Sweet' and Flor Branca acerolas fruit decreased in more than $60 \%$, during ripening. 'BRS 366' fruit maintained the highest levels with 4338 and $2631 \mathrm{mg}$ GAE. 100 $\mathrm{g}^{-1}$ at stages I and IV, respectively. The decrease in polyphenols content during ripening reduces fruit astringency leading to a desirable sensory quality and may be explained by polymerization or oxidation by polyphenoloxidase enzyme activity (SHWARTZ et al., 2009). Much though, the phenolic content in acerola is still high when compared to other fruits as papaya with $445 \mathrm{mg}$ GAE. $100 \mathrm{~g}^{-1}$, pineapple 
with $298 \mathrm{mg}$ GAE. $100 \mathrm{~g} \mathrm{~g}^{-1}$, tamarind with $122.2 \mathrm{mg}$ GAE.100 $\mathrm{g}^{-1}$ and soursop with $1491 \mathrm{mg}$ GAE.100 $\mathrm{g}^{-1}$ (ALMEIDA et al., 2011; SOUSA et al., 2012). The results found for vitamin $\mathrm{C}$ and polyphenol content indicates 'BRS 366' acerola fruit as a good source of bioactive compounds to be employed by the nutraceutical industry, especially at physiological maturity (stage I).

Among the polyphenols evaluated in acerola fruits, the anthocyanins and yellow flavonoids are the most abundant and anthocyanin content increased drastically with ripening, especially in 'Flor Branca' fruit reaching $12.37 \mathrm{mg} .100 \mathrm{~g} \mathrm{~g}^{-1}$, at stage IV. A previous work with other acerola varieties showed anthocyanin contents ranging from 0.19 to $47.4 \mathrm{mg} .100 \mathrm{~g}^{-1}$ (OLIVEIRA et al., 2012). The main anthocyanin were determined by HPLC-DAD-ESI/MS as two peaks were detected (Figure 2). Peaks 1 and 2 of mass spectrum show the most intense molecular ions $\mathrm{m} / \mathrm{z} 287$ and $\mathrm{m} / \mathrm{z}$ 271 corresponding to cyanidin 3 -rhamnoside and pelargonidin 3-rhamnoside, respectively. The latter one was detected only in ripe (stage IV) 'Florida Sweet' and 'Flor Branca' fruits and the greatest levels were observed in ripe 'Flor Branca' fruit, 520.76 mg. $100 \mathrm{~g}^{-1} \mathrm{DM}$ of cyanidin and $97.04 \mathrm{mg} .100 \mathrm{~g}^{-1}$ DM of pelargonidin, which may be directly related to the total anthocyanin content (Table 2).

According to De Rosso et al. (2008), cyanidin 3 -rhamnoside was also the main anthocyanin found in acerola from Waldy Cati 30 and Olivier varieties reaching $78 \%$ of its total content. Brito et al. (2007) also identified cyanidin 3-rhamnoside $(70 \%)$ and pelargonidin 3-rhamnoside $(30 \%)$ as the main anthocyanins in acerola. Thus, it is possible to concluded the sharp increase in the anthocyanin levels makes it the most important phenol present in ripe acerola (stage IV), as was also stated by Hanamura, Uchida and Aoki (2008).

Unlike anthocyanins, yellow flavonoid content increase slightly during ripening (stage IV) being highest in 'Flor Branca' fruit (9.82 mg. 100 $\left.\mathrm{g}^{-1}\right)$. Thereby, acerola cv. Flor Branca stands out in terms of flavonoids, anthocyanins and vitamin $\mathrm{C}$ contents which together must influence the soluble solids content found in stage IV fruit (Table 1), since the sugar levels were low (Table 1).

In all acerola varieties, the most abundant yellow flavonoid identified was quercetin 3-rhamnoside, taking into account the molecular ion at $m / z 303$ (Figure 3). Ripe stage IV acerola showed the highest levels of quercetin, especially for 'Flor Branca' and 'BRS 366' fruit with 33.72 and 27.81 mg.100 g-1 DM, respectively. Oliveira et al. (2012) found similar contents of quercetin in ripe 'BRS 237' acerola fruits, $33.49 \mathrm{mg} .100 \mathrm{~g}^{-1} \mathrm{DM}$.

The yellow flavonoid quercetin is a powerful antioxidant accumulated during ripening in acerola, adding to its nutritional bioactive properties. According to Hanamura, Kawagishi and Hagiwara (2005), the cyanidin-3-rhamnoside showed a strong neutralizing capacity of the superoxide radical $\left(\mathrm{O}_{2}^{-}\right)$, similar to that presented by quercetin and the authors explained that antioxidant activity is strongly correlated the number of B-ring hydroxyls of the structure of polyphenols. However and despite quercetin being present throughout acerola fruit development, its content was much lower when compared to cyanidin in stage IV fruits explaining the red color characteristic of ripe acerola fruit.

\section{Antioxidant enzyme activity}

Activity of all antioxidant enzymes evaluated in acerola pulp fruit decreased with development, but especially at ripening between III to IV (Table 3 ). The activity of SOD decreased significantly, but more drastically in 'Flor Branca' fruit from 3330.50 in stage I to $373.09 \mathrm{UA}^{\mathrm{U}} \mathrm{mg}^{-1} \mathrm{P}$ in stage IV. SOD belongs to a class of metalloenzymes that catalyze the degradation of superoxide anion $\left(\mathrm{O}_{2}^{-}\right)$into $\mathrm{H}_{2} \mathrm{O}_{2}$ and oxygen $\left(\mathrm{O}_{2}\right)$ and it is considered the first line of defense against reactive oxygen species (ROS) (HUANG et al., 2007).

In plant cells, the second defense line of the antioxidant enzymatic system is constituted of both CAT and APX which are involved with $\mathrm{H}_{2} \mathrm{O}_{2}$ scavenging, however APX uses ascorbate as the electron donor for $\mathrm{H}_{2} \mathrm{O}_{2}$ neutralization. CAT activity was the highest among the evaluated enzymes for the three acerola fruit varieties and it also declined significantly with development. Acerola fruit cv. Flor Branca presented the most drastic reduction in CAT activity, over $90 \%$ reaching $555.57 \mu \mathrm{mol} \mathrm{H}_{2} \mathrm{O}_{2} \cdot \mathrm{min}^{-1}$. $\mathrm{mg}^{-1} \mathrm{P}$. As for the other two evaluated enzymes, APX activity was higher in 'Flor Branca' fruit clone which decreased from 26.04 in stage I to $5.2 \mu \mathrm{mol} \mathrm{H}_{2} \mathrm{O}_{2}$. $\mathrm{min}^{-1} \cdot \mathrm{mg}^{-1} \mathrm{P}$, in stage IV. APX activity was much lower than CAT and as both enzymes use $\mathrm{H}_{2} \mathrm{O}_{2}$ as substrate, this result implies that CAT is possibly the main $\mathrm{H}_{2} \mathrm{O}_{2}$ scavenger in acerola fruit, which was also reported by Oliveira et al. (2012).

The enzymatic antioxidant defense system present is responsible for the removal of free radicals or ROS leading to protection against oxidative stress and therefore, increasing its postharvest conservation potential. Wang and Chen (2010) reported that fruits with better antioxidant enzyme systems showed a reduction in cell membrane damage which was 
related to longer periods of postharvest conservation due to a delay in senescence. Thereby, the data here presented indicates that 'Flor Branca' acerola fruit has a greater potential for postharvest conservation due to its higher antioxidant enzymatic activity.

\section{Total antioxidant activity}

TAA was significantly reduced for the three acerolas fruit evaluated during development (Table 3 ), but the steepest fall was found after physiological maturity from stage I to II. In ripe (stage IV) acerola fruit, 'BRS 366' showed the highest TAA with $42.36 \mu \mathrm{M}$ TEAC. $\mathrm{g}^{-1} \mathrm{FW}$, which can be justified by its high vitamin $\mathrm{C}$ and polyphenols contents (Table 2). However, variables may contribute differently to AAT as observed for 'Flor Branca' acerola fruit, which showed high contents of all phenolics evaluated although, comparatively low levels of vitamin $\mathrm{C}$, but still presented a high TAA.

Oliveira et al. (2011) studied the correlation between antioxidant compounds and TAA and reported that for acerola clone II 47/1, TAA was strongly correlated to $\mathrm{SS}$, as well as polyphenols and vitamin $\mathrm{C}$ contents. However, for 'BRS 235' acerola fruit, TAA and vitamin $\mathrm{C}$ were negatively correlated with SS, polyphenols and anthocyanins. These authors proposed a compensation system among antioxidants of non-enzymatic and enzymatic nature in acerola fruit, so those varieties with higher antioxidant enzyme activity showed lower nonenzymatic antioxidant levels and vice-versa.

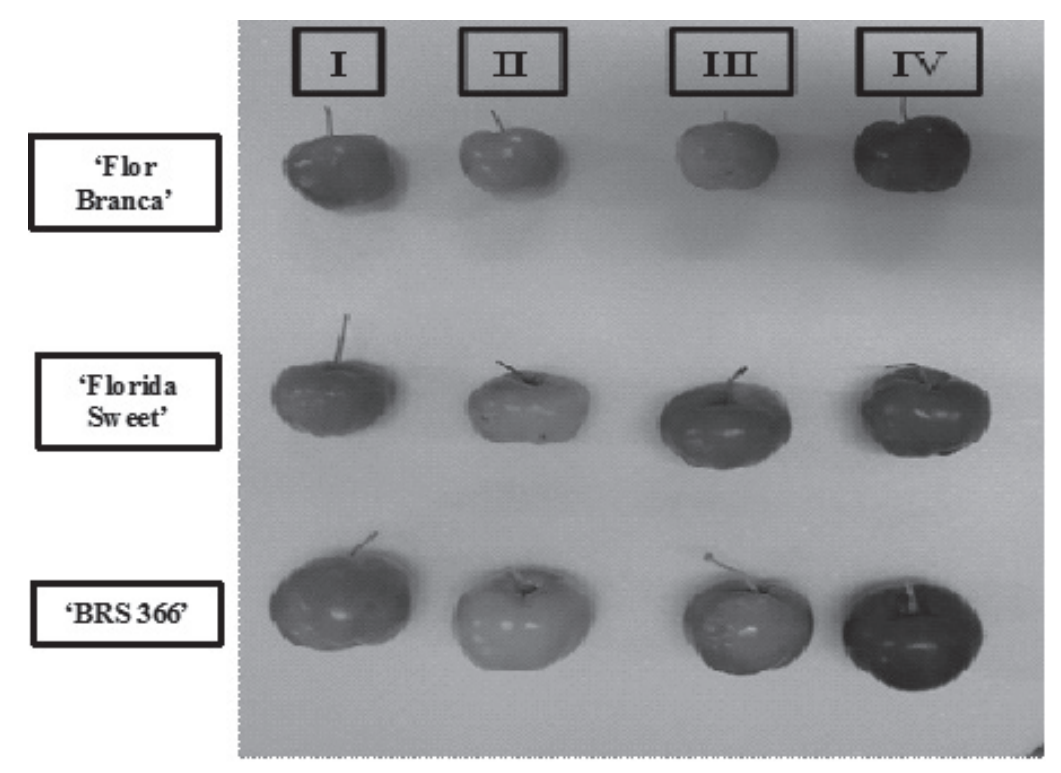

FIGURE 1- Acerolas fruit from cv. Flor Branca, Florida Sweet and BRS 366 at different developmental stages.

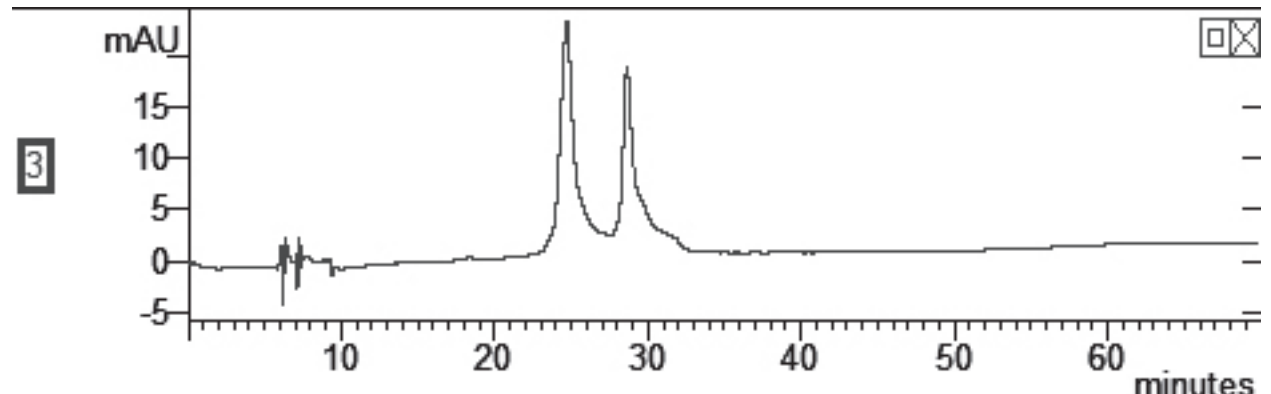

FIGURE 2- MS chromatogram at $512 \mathrm{~nm}$ of ripe fruit (stage IV) cv. Florida Sweet acerolas. Peaks $m / z 287$ ( $\mathrm{rt} 24.87 \mathrm{~min}$ ) for the molecular ion of cyanidin 3-rhamnoside and $\mathrm{m} / \mathrm{z} 271$ ( $\mathrm{rt} 29.81 \mathrm{~min}$ ) for the molecular ion of pelargonidin 3-rhamnoside. 


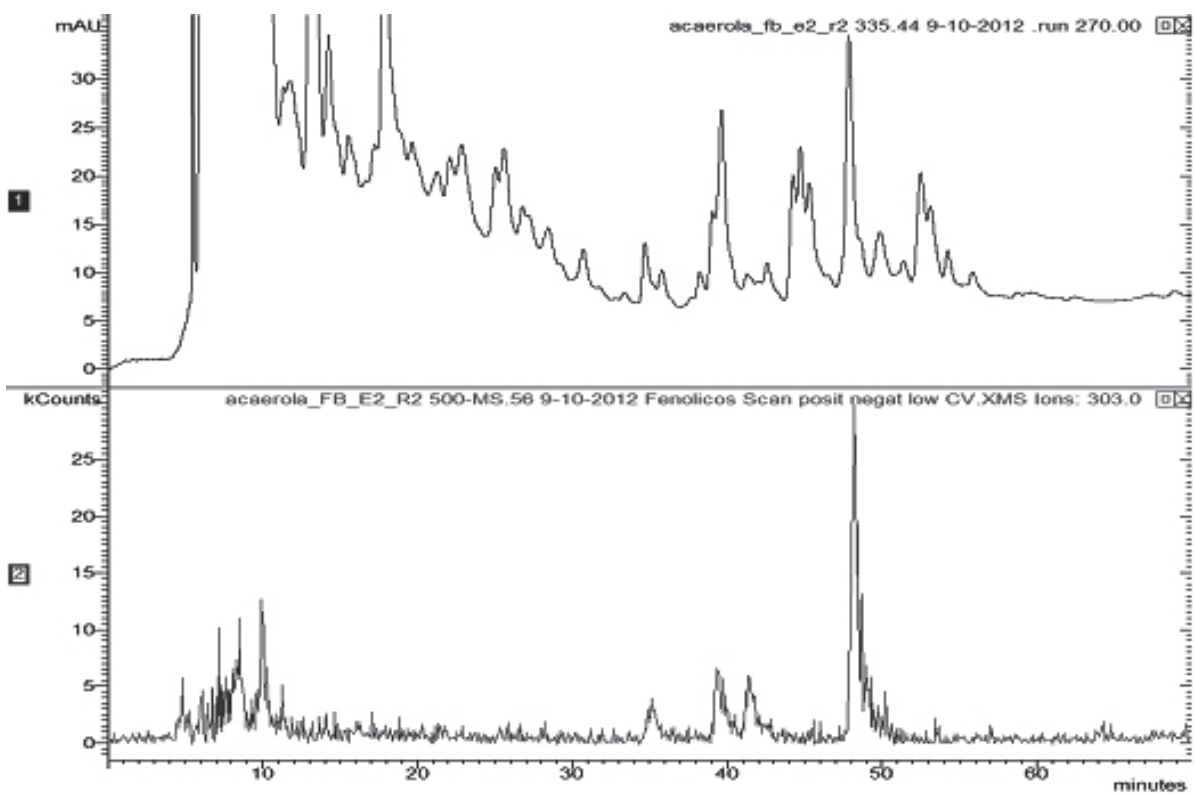

FIGURE 3- MS Chromatogram at $270 \mathrm{~nm}$ of physiologically mature fruit (stage II) cv. Flor Branca acerola. Peaks $m / z 303$ for the molecular ion of quercetin 3-rhamnoside.

TABLE 1- Changes in postharvest quality during development of different acerola fruit varieties. PacajusCE, 2011.

\begin{tabular}{ccccccc}
\hline \multirow{2}{*}{ CV } & Stage & $\begin{array}{c}\mathrm{SS} \\
\left({ }^{\circ} \mathrm{Brix}\right)\end{array}$ & $\begin{array}{c}\text { TA } \\
(\% \text { malic acid })\end{array}$ & $\mathrm{SS} / \mathrm{TA}$ & $\begin{array}{c}\text { Sugars } \\
(\%)\end{array}$ & $\mathrm{pH}$ \\
\hline \multirow{2}{*}{ 'Florida } & I & $7.06 \mathrm{Ab}$ & $0.90 \mathrm{Ba}$ & $7.80 \mathrm{Ab}$ & $3.59 \mathrm{Ab}$ & $3.55 \mathrm{Ac}$ \\
Sweet' & $7.76 \mathrm{Bb}$ & $0.84 \mathrm{Ba}$ & $9.24 \mathrm{Bb}$ & $3.77 \mathrm{Ab}$ & $3.56 \mathrm{Ac}$ \\
& III & $9.10 \mathrm{Cc}$ & $0.83 \mathrm{Ba}$ & $10.96 \mathrm{Cb}$ & $5.72 \mathrm{Bb}$ & $3.56 \mathrm{Ab}$ \\
& IV & $9.46 \mathrm{Cc}$ & $0.61 \mathrm{Aa}$ & $15.42 \mathrm{Db}$ & $6.03 \mathrm{Bb}$ & $3.68 \mathrm{Bc}$ \\
\hline \multirow{5}{*}{ 'Flor Branca' } & I & $5.50 \mathrm{Aa}$ & $1.15 \mathrm{Bb}$ & $4.78 \mathrm{Aa}$ & $1.60 \mathrm{Aa}$ & $3.29 \mathrm{ABb}$ \\
& III & $5.63 \mathrm{Aa}$ & $1.14 \mathrm{Bb}$ & $4.95 \mathrm{Aa}$ & $1.55 \mathrm{Aa}$ & $3.27 \mathrm{ABb}$ \\
& IV & $6.76 \mathrm{Bb}$ & $0.97 \mathrm{Ab}$ & $6.99 \mathrm{Ba}$ & $2.75 \mathrm{Ba}$ & $3.32 \mathrm{Bb}$ \\
\hline & I & $6.66 \mathrm{Cb}$ & $1.46 \mathrm{Cc}$ & $4.56 \mathrm{Aa}$ & $2.11 \mathrm{ABa}$ & $3.19 \mathrm{Aa}$ \\
'BRS 366' & II & $5.96 \mathrm{ABa}$ & $1.24 \mathrm{Bc}$ & $4.80 \mathrm{ABa}$ & $1.72 \mathrm{Aa}$ & $3.17 \mathrm{Aa}$ \\
& III & $5.46 \mathrm{Aa}$ & $1.17 \mathrm{Bb}$ & $4.67 \mathrm{Aa}$ & $2.48 \mathrm{Ba}$ & $3.20 \mathrm{Aa}$ \\
& IV & $6.33 \mathrm{BCa}$ & $1.06 \mathrm{Ac}$ & $5.98 \mathrm{BCa}$ & $2.32 \mathrm{Ba}$ & $3.18 \mathrm{Aa}$ \\
\hline
\end{tabular}

For each variable, different UPPERCASE letter indicates statistical difference at $\mathrm{p}<0.05$ between stages and lowercase letter indicates statistical difference at $\mathrm{p}<0.05$ between clones, according to Tukey's test. 

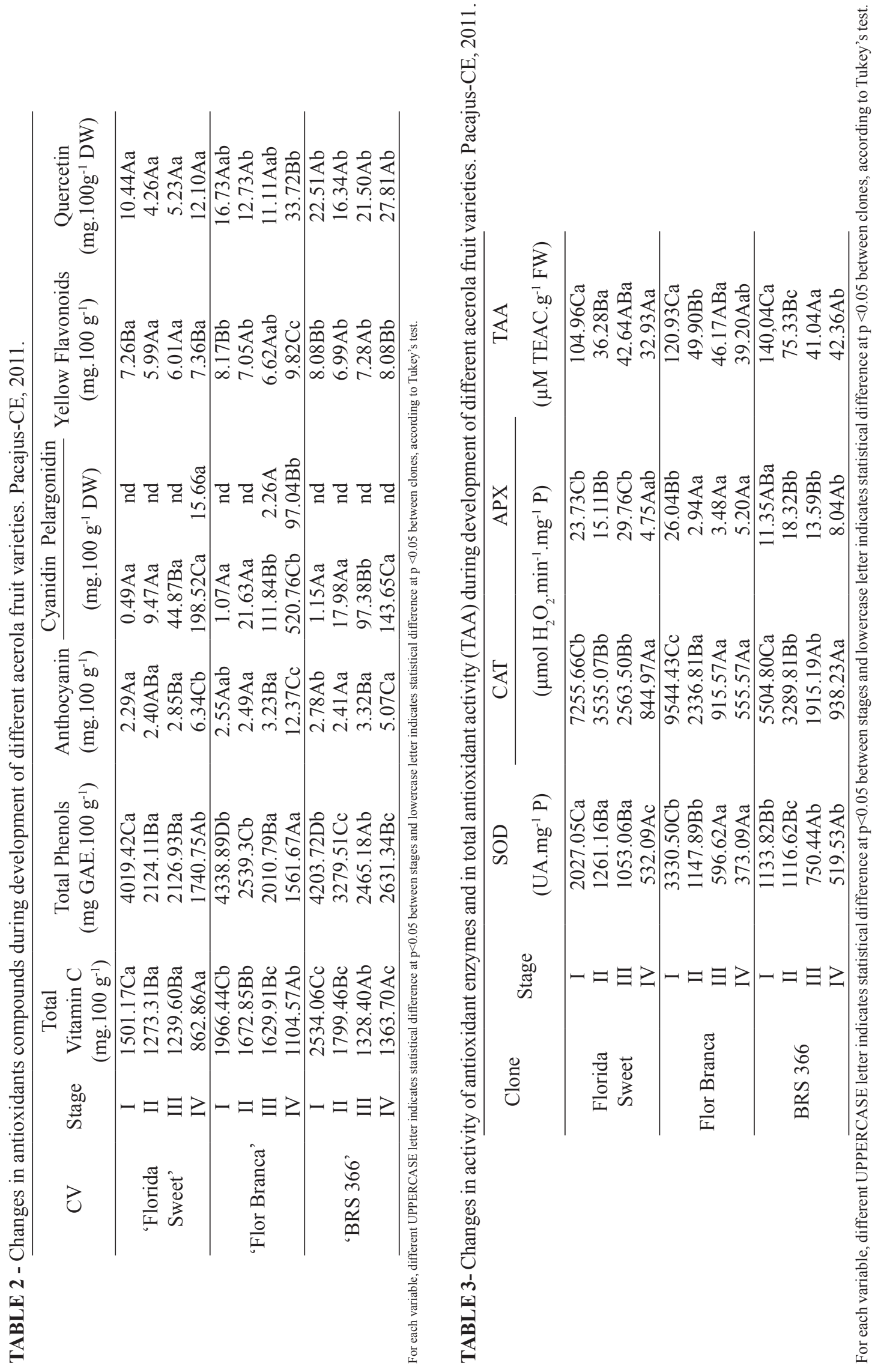


\section{CONCLUSIONS}

Ripe 'Florida Sweet' acerola fruit presented an exceptionally high sugar content highlighting its potential for fresh consumption. Polyphenol and vitamin $\mathrm{C}$ contents decreased more than $40 \%$ during ripening, however and despite of the observed decline, the evaluated acerola still presented high contents of such bioactive compounds. Based on the results found for bioactive compounds and for total antioxidant activity, physiologically mature 'BRS 366' acerola fruit seems the best option for the bioactive compounds processing industry. Among the polyphenols evaluated in acerola fruit, cyanidin 3-rhamnoside was the main anthocyanin and quercetin 3-rhamnoside was the most abundant yellow flavonoid. Activity of all evaluated antioxidant enzymes decreased especially at ripening, although 'Flor Branca' acerola fruit kept the highest activity levels, indicating a greater potential for postharvest conservation which, therefore, may be targeted for further studies on postharvest storage. APX activity was much lower than CAT which implies that the latter enzyme is possibly the main $\mathrm{H}_{2} \mathrm{O}_{2}$ scavenger in acerola fruit. Finally, it can be concluded that with ripening, the antioxidant metabolism of acerola fruit is suppressed due to the reduction in vitamin $\mathrm{C}$, in total phenolics and in activity of antioxidant enzymes reflecting in a decrease of total antioxidant activity.

\section{REFERENCES}

AGUDO, A.; CABRERA, L.; AMIANO, P.; ARDANAZ, E.; BARRICARTE,A.; BERENGUER, T. et al. Fruit and vegetable intakes, dietary antioxidant nutrients, and total mortality in Spanish adults: findings from the Spanish cohort of the European Prospective Investigation into Cancer and Nutrition (EPIC-Spain). American Journal of Clinical Nutrition, Bethesda, v.85, p.1634-1642. 2007.

AINSWORTH, E.A.; GILLESPIE, K.M. Estimation of total phenolic content and other oxidation substrates in plant tissues using Folin-Ciocalteu reagent. Nature Protocols, London, v.2, n.4, p.875877, 2007.

ALMEIDA, M. M. B.; SOUSA, P. H. M.; ARRIAGA, A. M. C.; PRADO, G. M.; MAGALHÃES, C. E. C.; MAIA, G. A. et al. Bioactives compounds and antioxidant activity of fresh exotic fruits from northeastern Brazil. Food Research International, Toronto, v.44, p.2155-2159, 2011.
AOAC. Official methods of analysis of the association of official analytical chemists. $18^{\text {th }} \mathrm{ed}$. Maryland, 2005. 850p.

BEAUCHAMP, C.; FRIDOVICH, I. Superoxide dismutase: improved assays and an assay applicable to acrylamide gels. Analytical Biochemistry, Oxford, v. 44, p. 276-287, 1971.

BEERS, Jr. R.F.; SIZER I.W. A Spectrophotometric method for measuring the breakdown of hydrogen peroxide by catalase. Journal Biology Chemistry, Rockville, v.195, p.133-140, 1952.

BRADFORD, M.M. A rapid and sensitive method for the quantitation of microgram quantities of protein utilizing the principle of protein dye binding. Analytical Biochemistry, Oxford, v.72, p.248-254, 1976.

BRITO, E.S.; ARAÚJO, M.C.P.; ALVES, R.E.; CARKEET, C.; CLEVIDENCE, B.A.; NOVOTNY, J.A. Anthocyanins present in selected tropical fruits: Acerola, Jambolão, Jussara and Guajiru. Journal of Agricultural and Food Chemistry, Easton, v.55, p.9389-9394, 2007.

COUTO, M. A. L.; CANNIATTI-BRAZACA, S. G. Quantification of vitamin $\mathrm{C}$ and antioxidant capacity of citrus varieties. Ciência e Tecnologia de Alimentos, Campinas, v.30, n.1, p.15-19, 2010.

DE ROSSO, V.V.; HILLEBRAND, S.; MONTILLA, E.C.; BOBBIO, F.O.; WINTERHALTER, P.; MERCADANTE, A.Z. Determination of anthocyanins from acerola (Malpighia emarginata D.C) and açai (Euterpe oleracea Mart.) by HPLCPDA-MS/MS. Journal of Food Composition and Analysis, Oxford, v. 21, p. 291-299, 2008.

FRANCIS, F.J. Analysis of anthocyanins. In: MARKAKIS, P. (Ed.). Anthocyanins as food colors. New York: Academic Press, 1982. p.181-207.

GIANNOPOLITIS, C.N.; RIES, S.K. Superoxide Dismutase. I. Occurrence in higher plants. Plant Physiology, Rockville, v. 59, p. 309-314, 1977.

GOMES, F.P. Curso de estatística experimental. Piracicaba: Ed. Nobel, 1987. 467p. 
HANAMURA, T.; HAGIWARA, T.;KAWAGISHI, $H$. Structural and functional characterization of polyphenols isolated from acerola (Malpighia emarginata DC.) fruit. Bioscience Biotechnology and Biochemistry, Tokyo, v.69, p.280-286, 2005.

HANAMURA, T.; USHIDA, E.; AOKI, H. Changes of the composition in acerola (Malpighia emarginata D.C) fruit in relation to cultivar, growing region and maturity. Journal of the Science of Food and Agriculture, Maiden, v.88, p.1813-1820, 2008.

HUANG, R.; XIA, R.; HU, L.; LU, Y.; WANG, M. Antioxidant activity and oxygen-scavenging system in orange pulp during fruit ripening and maturation. Scientia Horticulturae, Oxford. v. 113, p. 166 $172,2007$.

LACAN, D.; BACCOU, J. High levels of antioxidant enzymes correlate with delayed senescence in nonnetted muskmelon fruits. Planta, Berkeley, v. 204, p. 377-382, 1998.

LARRAURI, J. A.; RUPÉREZ, P.; SAURACALIXTO, F. Effect of drying temperature on the stability of polyphenols and antioxidant activity of red grape pomace peels. Journal of Agricultural and Food Chemistry, Davis, v.45, p. 13901393.1997.

LOPES, M. M. A.; MIRANDA, M. R. A.; MOURA, C. F. H.; ENÉAS-FILHO, J. Bioactive compounds and total antioxidant capacity of cashew apples (Anacardium occidentale L.) during the ripening of early dwarf cashew clones. Ciência eAgrotecnologia, Lavras, v. 36, n.3, p. 325-332, 2012.

MENICHINI, F.; TUNDIS, R.; BONESI, M.; LOIZZO, M. R.; CONFORTI, F.; STATTI, G.; De CINDIO, B.; HOUGHTON, P. J.; MENICHINI, F. The influence of fruit ripening on the phytochemical content and biological activity of Capsicum chinense Jacq. cv Habanero. Food Chemistry, London, v.114, p.553-560, 2009.

MOURA, C. F. H.; ALVES, R. E.; PAIVA, J. R.; FIGUEIREDO, R. W.; FILGUEIRAS, H. A. C.; QUEIROZ, D. L. Avaliações físicas e físico-químicas de frutos de clones de aceroleira (Malpighia emarginata D.C.). Ciência Agronômica, Fortaleza,v.38, n.1, p. 52- 57, 2007.
NAKANO, Y.; ASADA, K. Hydrogen peroxide is scavenged by ascorbate-specific peroxidases in spinach chloroplast. Plant and Cell Physiology, Oxford, v. 22, p. 867-880, 1981.

OLIVEIRA, L. S. O.; MOURA, C. F. H.; BRITO, E. S.; MAMEDE, R. V. S.; MIRANDA, M. R. A. Antioxidant metabolism during fruit development of different acerola (Malpighia emarginata D.C) Clones. Journal of Agricultural and Food Chemistry, Davis, v. 60, p. 7957-7964, 2012.

OLIVEIRA, L.S.; RUFINO, M.S.M.; MOURA, C.F.H.; CAVALCANTI, F.R.; ALVES, R.E.; MIRANDA, M.R.A. The influence of processing and long-term storage on the antioxidant metabolism of acerola (Malpighia emarginata D.C) purée. Brazilian Journal of Plant Physiology, Campos, v. 23, n.2, p. 151-160, 2011.

RUFINO, M.S.M.; ALVES, R.E.; BRITO, E.S.; MORAIS, S.M.; SAMPAIO, C.G.; PEREZ JIMENEZ, J.; SAURA-CALIXTO, F.D. Metodologia Científica: determinação da atividade antioxidante total em frutas pela captura do radical livre $\mathrm{ABTS}^{+}$. Fortaleza: Embrapa Agroindústria Tropical, 2006. 4 p. (Comunicado Técnico, 128)

SHWARTZ, E.; GLAZER, I.; BAR-YA'AKOV, I.; MATITYAHU, I.; BAR-ILA, I.; HOLLAND, D.; AMIR, R. Changes in chemical constituents during the maturation and ripening of two commercially important pomegranate accessions. Food Chemistry. London, v. 115, p. 965-973, 2009.

SILVA, B.M.;ANDRADE, P.B.; VALENTAO, P.; FERRERES, F.; SEABRA, R.M.; FERREIRA, M.A. Quince (Cydonia oblonga Miller) fruit (Pulp, Peel, and Seed) and jam: antioxidant activity. Journal of Agricultural and Food Chemistry, Davis, v.52, p.4705-4712, 2004.

SILVA, D. S.; MAIA, G. A.; SOUSA, P. H. M.; FIGUEIREDO, R. W.; COSTA, J. M.; FONSECA, A. V. V. Stability of bioactive compounds of unsweetened tropical guava juice obtained by hot fill and aseptic processes. Ciência e Tecnologia de Alimentos, Campinas, v.30, n.1, p.237-243, 2010.

SOUSA, V. R.; PEREIRA, P. A. P.; QUEIROZ, F.;BORGES, S. V.; CARNEIRO, J. D. D. S. Determination of bioactive compounds, antioxidant activity and chemical composition of Cerrado Brazilian fruits. Food Chemistry, London, v.134, p.381-386, 2012. 
STROHECKER, R.; HENNING, H.M. Analisis de vitaminas: métodos comprobados. Madrid: Ed. Paz Montalvo, 1967. 428p.

WANG, S.Y.; CHEN, C.T. Effect of allylisothiocyanate on antioxidant enzyme activities, flavonoids and post-harvest fruit quality of blueberries (Vaccinium corymbosum L., cv. Duke), Food Chemistry, London, v. 122, p. 1.153-1.158, 2010.
YANG, Z.; ZHENG, Y.; CAO, S. Effect of high oxygen atmosphere on quality, antioxidant enzymes, and DPPH-radical scavenging activity of Chinese bayberry fruit. Journal of Agricultural and Food Chemistry, Davis, v.57, p.176-181, 2009.

YEMN, E. W.; WILLIS, A. J. The estimation of carbohydrate in plant extracts by anthrone. The Biochemical Journal, London, v.57, p.508-514, 1954. 